\title{
ANALYSIS OF THE USE OF OUTSOURCING SERVICES FOR MAINTENANCE AND REPAIR OF THE EQUIPMENT AND ARMAMENT AVAILABLE IN THE STRUCTURES OF THE BULGARIAN ARMED FORCES
}

\author{
Nikolay STEFANOV \\ “Vasil Levski” National Military University, Veliko Tarnovo, Bulgaria \\ niki.s@abv.bg
}

\begin{abstract}
The longlasting process of transformation of the armed forces, as well as the reduction of staff resulted in the loss of certain capabilities. In times of transformation, the different structures of the Bulgarian Armed Forces, led by the desire to preserve their most important capabilities, namely the combat ones, are forced to lay off mainly parts of their maintenance and support units. In order to compensate for these lost capabilities, the armed forces resorted to the use of outsourcing services for the repair and maintenance of armament and military equipment. This article studies and analyses the use of outsourcing services for the maintenance and repair of equipment and armament available in the structures of the Bulgarian Armed Forces.
\end{abstract}

Keywords: outsourcing services, analysis, Bulgarian Armed Forces, repair of equipment and armament

\section{Introduction}

The main objective of the implementation of outsourcing services in the armed forces is the acquisition of resources that are needed to manage the main areas of activity at a professional level.

From an organisational perspective, we talk about simplification of management and organisational structure. This leads to increasing specialisation of the staff and the management of the armed forces. Thus, the use of outsourcing is not necessarily just a matter of financial results, but it also enhances the culture in the military.

In our specific conditions, the implementation of outsourcing can only be justified by cost savings. Another very important factor is the cultural change throughout the organisation. In the military environment, this change in culture is a fundamental point. It is related to the growing negative attitude towards military service in society.

The main objective of the reform of the armed forces is their modernisation. In this case, this does not mean that they only get equipped with the latest technologies, materials and weapons, but also have a modern internal organisation aimed at effective execution of core tasks. From this perspective, it is not just a question of finance, but also a way of thinking and internal culture of the organisation. Finance can accelerate these processes, but it cannot stop them in any way.

The implementation of outsourcing services in the armed forces is seen as a result of close interaction between the service provider and the armed forces in the role of user, and the inside activity of the provider related to satisfying the needs of the armed forces [13].

2. Analysis of the state of applicable outsourcing services in the structures of the Bulgarian Armed Forces

As far as military operations are conducted by the humanity only in exceptional cases, but maintaining the armed forces has to be permanent, the preparation of combat 
activities lies on the state as a heavy burden [12]. The modernisation of the military, the optimisation of the staff, and the reduction of costs are directly related to the outsourcing of certain ancillary and service activities. In this connection, the report on the, section 5 Maintenance and Security Defence, says: "In 2009, some of the main tasks of this sector policy were the construction of a certified secure information system, continuing the process of military standardisation, certification and codification, armaments, equipment and property, development and implementation of measures for the formation of a sustainable positive public attitude towards the activity of the Ministry of Defence, and in particular the participation of the Bulgarian Armed Forces in operations abroad, as well as outsourcing of service activities" $[4,14,15]$.

This leads to the conclusion that the Ministry of Defence holds a steady policy concerning the use of outsourcing services, despite the conflicting results and the claim of the former Defence Minister Anyu Angelov that the transfer of certain activities to external contractors does not result in cost savings, which is the main goal, but even has a the opposite effect.

Overall, outsourcing services prevent the appearance of corruption. Using outsourcing helps to overcome the causes for the appearance of corruption or to restrict it [10]. Outsourcing is associated with reducing corruption pressure by improving the organisation and technology of the activities and services in the formations of the Bulgarian Armed Forces, and with improving the effectiveness of internal departmental and civil control in the Ministry of Defence of the Republic of Bulgaria.

According to the structures of the Ministry of Defence, engaged in the activities on planning and preparation of reports on outsourcing contracts, "the percentage of return for the various activities is different, and it will not be accurate if a total approximate percentage is specified." They refuse to provide specific data or evidence, but say that after outsourcing certain activities, their cost is reduced. When asked about the transfer of which activities is assessed as profitable and with which ones the ministry incurs losses, the administration states that "the analyses and estimates show greater efficiency in the use of outsourcing, but only when the contractor has completed the contracts properly and with the desired quality." In a report of his, the former Deputy Defence Minister Valentin Radev says that by using this mechanism, the MoD reduces the cost of maintaining defence capabilities [8].

Dimitrova, Nichev and Stefanov (2015) consider that outsourcing within the armed forces means using the capacity of private sector management of such activities previously carried out by personnel of the armed forces or their civilian employees [9]. The number of outsourcing contracts signed in the structures of the Bulgarian Armed Forces from 2009 until today varies every year. For example, in 200918 outsourcing contracts were concluded mainly for providing catering services, security of military installations, maintenance and repair of equipment and armament [4]. In 2010, 27 contracts were signed or extended for services such as maintenance of communication and information systems, software and equipment, maintenance of a system for flight and landing control on military airports, security of military installations, repair and maintenance of transport equipment, air-conditioning equipment, elevators, etc [5]. In comparison, in 2011 only three contracts were concluded for activities related to the repair and maintenance of equipment and armament [8]. After 2011, there is a significant increase in the number of outsourcing contracts signed in the sphere of the armed forces, and the focus was again primarily on security, repair and maintenance of equipment, catering, etc [5]. Both the reduction and the increase in the 
number of such contracts executed by the Ministry of Defense of the Republic of Bulgaria over the years (Figure 1) is due to the fact that in most cases they are longterm, that is concluded for more than one year.

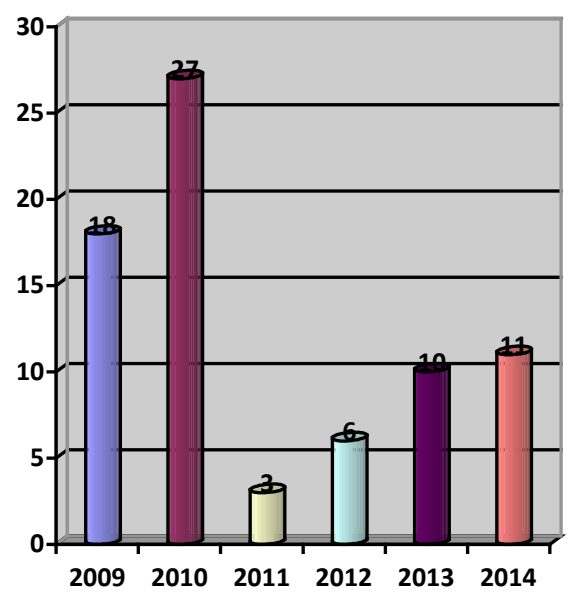

Figure 1: Number of contracts for outsourcing services from 2009 to 2014

The given personal interviews by military personnel support the fact that some of the most commonly used outsourcing services in the armed forces currently are the provision of food for the personnel of military units, repair, maintenance of equipment and armament, and security of the military areas. This is the reason why we will look at one of this type of outsourcing in this article.

\section{Analysis of the use of outsourcing services for the maintenance and repair of equipment and weapons available in the structures of the Bulgarian Armed Forces}

Both the long process of transformation of the armed forces and the reduction of personnel have contributed to the loss of certain capabilities. In times of transformation, the different structures of the Bulgarian Armed Forces, led by the desire to preserve their most important capabilities, namely the combat ones, are forced to lay off mainly parts of their maintenance and support units. In order to compensate for these lost capabilities, the armed forces resorted to the use of outsourcing services for the repair and maintenance of armament and military equipment. Historically, this practice is not new, but it applies only when performing general overhauls. [2,3,11]

For the purposes of this analysis, it is necessary to clarify the scope of applicability of the concepts of operation and technical maintenance in the structures of the Bulgarian Armed Forces.

In view of the specific activities of the Bulgarian Armed Forces, the operation of armament and equipment includes their intended use, timely and full-volume maintenance and proper storage.

The methodological basis for this is the regulatory framework for establishing the rules and standards for operation (concepts, doctrines, manuals, regulations, handbooks, methods) of the Defence Ministry. On the basis of this framework, the Armed Forces develop their handbooks, statutes, manuals and procedures relating to systems of armaments and equipment typical of the branch of the armed forces which exploits them.

According to the doctrine of logistics, the technical maintenance of equipment and armament combines all activities and procedures related to cleaning, lubrication, replenishment, diagnostics and minor repairs related to the replacement of worn elements and / or elements whose resource has expired (parts, assemblies and aggregates) and materials in order to maintain the material resources in good condition. In some cases, the maintenance may include replacement of weapons [6].

The exploitation and maintenance of the operational new equipment in recent years justifies the use of outsourcing services for these activities by the military structures.

In 2001, outsourcing was first implemented and is still used to ensure the maintenance of the fleet of vehicles of the Ministry of Defence.

Thus, the lack of expertise on the maintenance and repair of new and more 
sophisticated automobiles was compensated for as they were different from the Russian vehicles, which the Bulgarian Armed Forces were equipped with and prepared to maintain by then.

With the acquisition of new transport equipment, the larger units (off-road vehicles, trucks and Mercedes buses) started to use outsourcing for its maintenance and repair.

According to data provided by the Ministry of Defence at the request of Mediapool, the three outsourcing contracts signed in 2011 are at a total cost of about 440,000 Bulgarian levs, and include activities related to the repair and maintenance of equipment and armament.

It is thus obvious that the Defence Ministry continues to rely heavily on outsourcing, despite the conflicting results and the Minister of Defence Anyu Angelov's claim that the transfer of certain activities to external contractors does not lead to cost savings, which is the main goal, but even has the opposite effect [8].

Regardless of this opinion, over the years of operation of the Plan for Development of the Armed Forces by 2014, the trend was towards an increase of the use of outsourcing services by the armed forces in the sphere of repair and maintenance of equipment and weapons, as the data in Figure 2 show [7].

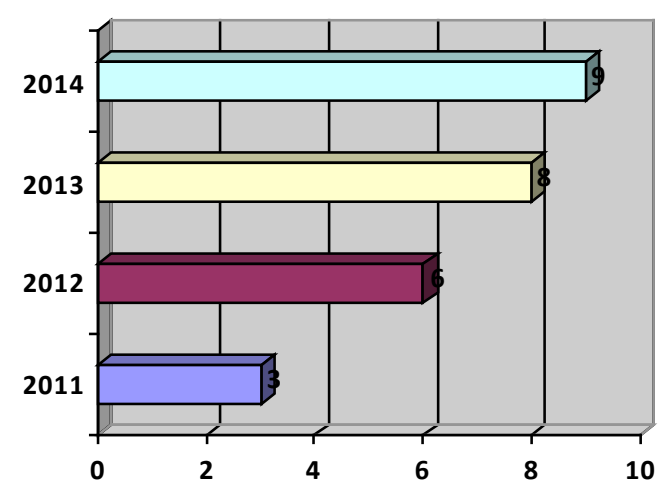

Figure 2: Number of outsourcing contracts for services in the sphere of repair and maintenance of equipment and armamament from 2011 to 2014
Studying the documents database of the Defence Acqusition Directorate and the orders made at the Public Procurement Agency in the field of defence and security for the period from 2011 to 2014, it appears that the Bulgarian Armed Forces used outsourcing in the field of repair and service. After this research, it has become even more apparent that outsourcing has not only been used for maintenance and repair of combat and transportation equipment and armament, but also in terms of both communication and information equipment, equipment for food storage and the equipment used for the maintenance of military areas.

In all the above mentioned cases, the activity takes place constantly in military units, not just once (contracts are usually concluded for several years). It is also one of the features that distinguishes outsourcing from simple counselling or the typical use of external mechanised services. In counselling it is only recommendations that are given on how to achieve the desired result, while in outsourcing the relevant specialists embody their advice into practice. In the first case, the military unit benefits from advice, and in the second one - payment is received against an outcome, and besides that, the customer is held liable on the way the money is spent.

In traditional outsourcing agreements for external mechanised services, it is usually a question of delegating an activity that the armed forces, for one reason or another, can not currently carry out by themselves; however, no efforts to transfer it completely and longterm can be noticed. A good example for this is the contract with an outside contractor for conducting repairs or a replacement of a particular unit in a certain type of equipment that due to insufficient capacity (lack of trained professionals in this field) the military unit could not perform on its own within favorable service deadlines. Certainly, in cases when the specific military structure decides that in the future there is no 
possibility to carry out this type of mechanised service and signs a long-term contract for external services with another organisation, which is subject to certain requirements, only then this may be referred to as outsourcing [1].

The use of outsourcing by the Bulgarian Armed Forces for services related to maintenance, repair and servicing of various types of equipment is driven by the desire to provide better quality services at lower costs.

\section{Conclusion}

Despite all the negatives, it is an undisputed fact that outsourcing is increasingly used in the armed forces and proves its efficiency in making decisions related to the spending of financial resources for security and defence. Undoubtedly, when choosing between "for" or "against" outsourcing services, it is necessary to analyse each and every outsourcing contract and assess its cost-effectiveness and benefits for the Bulgarian Armed Forces and how appropriate an alternative it is related to a certain activity for the Defence Ministry. Making the decision to outsource certain activities should be based on the analysis of the advantages and disadvantages of using outsourcing, on evaluating the costs of the various options for implementing the activity, of possible risks in its use and the objective comparison of alternatives on the basis of an acceptable balance between quality and cost.

\section{References}

[1] Georgieva, V., "Outsourcing of Processes Related to the Vehicle-Tractor Fleet in the Agrarian Sector", Scientific Works Volume LVIII, Academic Publishing House of the Agricultural University in Plovdiv, 2014.

[2] Parashkevova, A. D., "Strategy for the Organisation of Termination of an Outsourcing Contract", Scientific Almanac, Issue 8 of the Chernorizets Hrabar Varna Free University, 2011, pp. 172-183.

[3] Peycheva, K., "The crisis in Security and Defence Before and During the Economic Crisis", Almanac of G. S. Rakovski Defence College 2012, National Security and Defence Faculty, pp. 93-111.

[4] Report on the State of Defence and the Armed Forces of the Republic of Bulgaria in 2009, http://www.mod.bg/bg/doc/drugi/20100413_Report_2009.pdf.

[5] Report on the State of Defence and the Armed Forces of the Republic of Bulgaria in 2010, http://www.md.government.bg/bg/doc/ drugi/20110323 DokladMS_SustoianieVS.pdf.

[6] Doctrine for Logistics, Sofia 2013, www.mod.bg/bg/doc/drugi/ 20130916_Doktrina_logistika.pdf 28.10.2015.

[7] Investments in Defence made by the Ministry of Defence, Procurements, http://io_old.mod.bg/archive 02.11.2015

[8] The MoD Will Not Give up on Outsourcing Even Though it is Not Cost Effective, http://www.mediapool.bg/mo-ne-se-otkazva-ot-autsorsinga-vapreki-che-e-na-zagubanews181723.html. 05.10.2015

[9] Sevdalina Dimitrova, Nikolay Nichev, Nikolay Stefanov "Development of Outsourcing Services" (2015) International Conference on Knowledge-Based Organisations, Volume 21, Issue 1, pp. 192-197

[10] Terziev, V., Nichev, N., Bankov, S., Corruption and National Security. (2016) International Scientific Journal “Innovation Research”, №10, part 3, pp. 189-196

[11] Harizanova, M. "Outsourcing: Role, Characteristics and Trends of Application" Scientific Works, Volume 2/2012 
[12] Terziev, V., Filipov, S., Ninth International Scientific Conference 17-19.6.2016, Durres, Republic of Albania "Characteristics and Elements of Military Infrastructure", Volume 13.1, p. 301

[13] Banabakova, V., Stefanov, Sv., State and Development of Logistics Services in Bulgaria. Land Forces Academy Review, Sibiu, Romania, N. 2, 2013, pp. 156.

[14] Petrova, E., Nichev, N., Financing and Place of the Bulgarian Army in the Operations of International Crisis Management, Revista Academiei Fortelor Terestre, NR. 3 (75), Sibiu, Romania, Nicolae Balcescu Land Forces Academy, 2014, pp. $307 \div 312$.

[15] Petrova, E., A Review of the Expenditures on Defence of the Republic of Bulgaria for 2010-2015, Revista Academiei Fortelor Terestre, NR. 4 (80)/2015, Nicolae Balcescu Land Forces Academy, Sibiu, Romania, pp. $488 \div 496,2015$. 